\title{
Performance increments without audience: paired data from mixed martial arts fighters during COVID-19
}

\author{
Tony BLOMQVIST MICKELSSON* (D) \& Vince SHAW \\ Department of Social Sciences, Södertörn University (Sweden)
}

Received: 29/08/2020; Accepted: 30/11/2020; Published: 03/12/2020.

ORIGINAL PAPER

\begin{abstract}
During COVID-19, athletes have been forced to compete in the absence of audience. Athletic and cognitive performance have been shown to be both incremented and decremented when competing either with or without audience, something that has been termed 'social facilitation'. The current study sought to investigate this effect in a naturalistic experiment due to the current pandemic, in a sport in which the effect has never been examined; mixed martial arts (MMA). A performance variable was constructed, and data from 86 fighters who competed during COVID-19 were collected and compared to previous competition history. In total, 586 bouts were analyzed. Data distribution and assumptions were explored in which non-normal distribution was found. Subsequently, a test of marginal homogeneity and a Wilcoxon Signed Ranks test were performed. The results showed that MMA fighters who won their bout without audience displayed poorer performance's in previous bouts, which were attended by audience. The current study further explores the notion of social facilitation effects and suggests there may be a need to pro-actively incorporate training alternatives that could mitigate performance decrements in fighters who are prone to negative effects due to external stimuli, such as an audience. However, due to the limited observations in the non-audience condition the study results should be interpreted cautiously and considered highly preliminary.
\end{abstract}

Keywords: Combat sports; martial arts; mixed martial arts; COVID-19; performance analysis; social facilitation.

\section{El rendimiento mejora en ausencia de espectadores: datos pareados de luchadores de artes marciales mixtas durante la COVID-19 \\ Resumen}

Durante la COVID-19, los deportistas han tenido que competir sin público. Se ha demostrado que el rendimiento deportivo y cognitivo puede aumentar o disminuir al competir con o sin espectadores, lo se ha denominado "facilitación social". Este estudio investigó este efecto mediante un experimento naturalista debido a la pandemia actual, en un deporte, las artes marciales mixtas (MMA), en el que nunca había sido analizado. Se construyó una variable de rendimiento y se recopilaron datos de 86 luchadores que compitieron durante la COVID-19, comparándolos con sus historiales de competiciones anteriores. En total, se analizaron 586 combates. Se exploró la distribución de datos y los supuestos estadísticos, encontrando una distribución no normal. Seguidamente, se realizó un test de homogeneidad marginal y un test de Rangos con Signo de Wilcoxon. Los resultados mostraron que los luchadores de MMA que ganaron su combate sin audiencia mostraron un peor rendimiento en combates anteriores, con espectadores. Este estudio profundiza en la noción de efectos de facilitación social y sugiere que puede existir la necesidad de incorporar de forma proactiva alternativas de entrenamiento, que podrían mitigar la disminución de rendimiento en luchadores propensos a sufrir este efecto negativo debido a estímulos externos, como son los espectadores. Sin embargo, debido a las observaciones limitadas en la condición de sin espectadores, los resultados de este estudio deben

\section{Aumentos de desempenho sem público: dados comparados de lutadores de artes marciais mistas durante a COVID-19}

\section{Resumo}

Durante a COVID-19, os atletas foram forçados a competir na ausência de público. Foi demonstrado que o desempenho atlético e cognitivo aumenta e diminui ao competir com ou sem público, algo que foi denominado "facilitação social". 0 presente estudo procurou investigar esse efeito num experimento natural devido à pandemia atual, num desporto em que o efeito nunca foi examinado: artes marciais mistas (MMA). Uma variável de desempenho foi construída e dados de 86 lutadores que competiram durante a COVID-19 foram recolhidos e comparados com o histórico de competições anteriores. No total, 586 lutas foram analisadas. A distribuição dos dados e os pressupostos foram explorados, nos quais foi encontrada uma distribuição não normal. Posteriormente, foi realizado um teste de homogeneidade marginal e um teste de Wilcoxon Signed Ranks. Os resultados mostraram que lutadores de MMA que venceram a luta sem público apresentaram piores desempenhos nas lutas anteriores, que contaram com a presença do público. 0 estudo atual explora ainda a noção de efeitos de facilitação social e sugere que pode haver uma necessidade de incorporar proativamente alternativas de treino que poderiam mitigar decréscimos de desempenho em lutadores que são propensos a efeitos negativos devido a estímulos externos, como uma audiência. No entanto, devido às observações limitadas na condição de não público, os resultados do estudo devem ser interpretados com cautela e 
interpretarse con cautela y considerarse muy preliminares. Palabras clave: Deportes de combate; artes marciales; artes marciales mixtas; COVID-19; análisis de rendimiento; facilitación social. considerados altamente preliminares.

Palavras-chave: Desportos de combate; artes marciais; artes marciais mistas; COVID-19; análise do rendimento; facilitação social.

\section{Introduction}

MMA is a combat sport in which practitioners are allowed to utilize both striking and grappling techniques (Spencer, 2009). The sport has experienced a tremendous growth in popularity (Blue, 2013), and both physiological (e.g., La Bounty et al., 2011), sociological (e.g., Spencer, 2009), psychosocial aspects (e.g., Blomqvist Mickelsson, 2020) and performance aspects (e.g., James et al., 2019) have increasingly become subject for more in-depth investigation, although the general research around MMA remains largely under explored (Jensen et al., 2013). The absence of MMA research is evident, as recent reviews on physiological foundations in combat sports did not include any study on MMA at all (James et al., 2016) or concluded that the nature of the physiological research on MMA athletes are primarily descriptive and weak (Kirk et al., 2020).

MMA has been argued to be the most extreme sport currently existing, and athletes have been said to be the ancient gladiator era's equivalents (García \& Malcolm, 2010). Thus, naturally, the sport of MMA has been shown to elicit great amounts of fear in practitioners and the psychological demands are extreme. For example, it is not uncommon for fighters to report feelings of fear and worry, and even throw up in pre-fight anxiety (Vaccaro et al., 2011). A recent review of the sport psychological applications in MMA reported that addressing fear and emotional control in MMA fighters were the most common (Andrade et al., 2020), thus highlighting the salient role of fear in this particular sport.

Except for the violent, chaotic and thus worrisome nature of the sport (Jensen et al., 2013), which naturally produces mental tension, fighters report that losing and being injured are common worries which may interfere with performance (Vaccaro et al., 2011). The fear of losing is connected to the humiliation one may experience when being defeated in front of peers and family and the fear of being embarrassed for athletes are elevated when evaluated and judged by present peers (Ribeiro et al., 2013). It is not exclusively familiar peers who may impact an athlete's performance, as recent research has shown how for example basketball players performance are affected by sheer audience size (Böheim et al., 2019). This effect has also been shown when bench spotters are present (Sheridan et al., 2019), presence of verbally active peers in cycling tests (Edwards et al., 2018) and when in company of other competitors (Hibbert et al., 2018). In other words, the present audience may play a partial but significant role in the fighter's performance. Furthermore, it has also been reported that mere presence may not be enough to impact performance; instead, 'evaluative' presence may affect performance (Claypoole \& Szalma, 2018). The audience in large scale events may be argued to be of evaluative nature, and it does not seem to matter performance-wise whether the audience is familiar- or non-familiar peers (Carnes et al., 2016), however, the response from the audience do seem to impact the performance (Greer, 1983).

Social facilitation theory argues that performance may either be facilitated or crippled by the presence of an audience. Originating from Triplett (1898), it was observed that cyclists performed better when competing against one another, rather than cycling alone. Thus, Triplett (1898) argued that the presence of others significantly elevated the individual's performance. Since the entry of social facilitation theory, several sub-theories of social facilitation have emerged. According to the capacity mode (Manstead \& Semin, 1980), activities which requires high cognitive effort will impair the performance when an audience is present. Manstead and Semin (1980) argue that, while simple processes do not require any additional attention or capacity when others are present, complex and difficult tasks require more cognitive efforts. When engaging in a difficult task, the presence of an audience would present yet another element that may draw attention to it, thus impairing the performance. An MMA bout in itself is an event that may be argued to demand large amounts of mental effort and may thus affect executive functions such as attention span, decision-making and self-regulation; all of which are crucial for performance in the current context. The addition of external stimuli such as an audience may thus exacerbate the cognitive demands and ultimately lead to performance decrements. 
The actual mechanisms and empirical effects stemming from social facilitation theory are not entirely clear. Bond and Titus (1983) performed a metanalysis of 241 studies and close to 24000 participants in which the authors reported that social facilitation may facilitate performance when performing simple tasks but decrease performance when performing complex tasks. The effect of the presence of an audience was estimated to range from .3 to 3 percent, thus indicating a small effect. However, at the very highest level of elite sport, small effects and marginals may be the difference between a win and a loose.

As are all other sporting events, combat sports events are regularly attended by many people. However, in the midst of COVID-19, the majority of sport events have been cancelled. One exception is that of the Ultimate Fighting Championship (UFC) which continues to produce MMA events. In order to comply with epidemiological recommendations (Viner et al., 2020), these events have been arranged to only accommodate the fighters and relevant staff (e.g., judges, speakers, coaches), while the regular audience are not allowed to attend. This presents a peculiar situation to that of the fighters; UFC fighters usually perform in front of thousands of people live, whereas they are now fighting in front of an extremely limited amount of people which only consists of personnel. Additionally, some of the personnel is not even attending the actual bouts, instead they handle the logistics surrounding the event. Despite the unfortunate state of the world, this presents an opportunity in the shape of a naturalistic experiment to examine how the absence of an audience may impact a fighter's performance on the highest level, which would never occur otherwise. Currently, the absence of audience due to COVID-19 has only been investigated in football (Reade et al., 2020) which indeed indicated significant changes in referee behavior.

The current study sought to answer how a fighter's performance is affected by the absence of audience. Guided by the capacity model, fighters who are prone to 'choking' effects and increased cognitive load due to external stimuli would thus display improved performances without audience. In an MMA bout, and any contest for that matter, being successful is defined by winning. On the basis of this, we hypothesized that fighters who had won their bout(s) during COVID-19 (i.e., without audience) would display poorer performances in their bouts prior to COVID-19 (i.e., with audience).

\section{Methods}

\subsection{Participants}

Data included 86 elite athletes (73 males, 13 females), competing in the UFC. Inclusion criteria were 1) competing in at least one non-audience show due to COVID-19 in the UFC, 2) winning by way of decision, submission or TKO/KO but not by disqualification, 3) making the weight-limit set out for the fighter, 4) having fought in a minimum of two bouts in the UFC since 2017 prior to the non-audience bout and 5) that three round bouts and not championship bouts had been completed. The criteria were determined in order to avoid undecisive results (e.g., draws) and to make sure no fighter had an initially weight-related advantage. It was also decided that, given that the UFC compromises the highest level of fighters, the included bouts needed to take place within the organization to ensure that the quality and difficulty of fights were held somewhat constant. Additionally, it has been shown that championship bouts may change in bout characteristics, thus their exclusion (Miarka et al., 2019). Finally, the included bouts (a minimum of three bouts prior to the non-audience bout ranging from 2017 to 2019) that were subject to analysis were decided upon the construction of a performance variable in order to increase statistical power and representativeness of fighters' performance, further described in the procedural section.

\subsection{Procedure}

Data were collected between 14th of March 2020 and 22th of July 2020, and the raw data were obtained from Sherdog, one of the oldest and most established MMA media outlets currently existing which keep track of events and fighters. The collected raw data contained the record of fighters, fight outcomes (i.e., wins and losses), the method of winning or losing (decision, submission, KO/TKO) and round time. 
A performance factor was created on the basis of merging method of win (i.e., decision, submission or TKO/KO) and round time (i.e., round one to three). Being able to finish an opponent instead of going to decision was argued to indicate a more dominant performance and being able to finish an opponent in earlier rounds were considered more dominant than finishing in later rounds. Although this may not reflect the entire bout and its characteristics, it is plausible that a very dominant fighter would finish an inferior fighter earlier than later. The factor contained eight levels of performance indicators based on method of outcome and time, ranging from 1 to 8 , where low scores indicated poorer performance and higher scores indicated better performance $(1=$ finished in first round; 2 = finished in second round; $3=$ finished in third round; $4=$ loss by decision; $5=$ win by decision; $6=$ win by third round finish; $7=$ win by second round finish; $8=$ win by first round finish).

Furthermore, the experimental condition (i.e., the bouts without audience) was limited to one, and in rare cases two bouts, simply because the study took place in the beginning of the pandemic outbreak. However, the control condition (i.e., the audience-attended bouts) was subject for modification, as it did not have to rely on a single bout. In order to create a more appropriate control condition, all bouts starting from 2017 up until the non-audience bout were analyzed. Given the rapid evolution of MMA due to its popularity (Blue, 2012), the cut-off from 2017 were thoroughly discussed between authors. The cut-off was determined in order to limit confounding effects due to drastic changes in physical, technical, tactical and mental skill level- and style, and other time dependent matters that may affect a fighter's performance, as recent longitudinal research reports that winning characteristics in UFC-fighters indeed vary with time (James et al., 2019). To this end, we attempted to increase the statistical representativeness of the control condition while maintaining the conditions as similar as possible, except for the absence of audience.

Frequencies were counted as the performance variable was treated as a categorical variable; to add more context to the results, we also decided to compare the performance in the winning bouts in both conditions. To this end, we removed all of the losses and computed the mean and standard deviation of the competitor's bout time.

\subsection{Statistical Analysis}

Prior to data collection, a power calculation was performed in G*Power 3.1 (Faul et al., 2009). The power calculation was based on the comparison of two dependent means (i.e., paired $t$ test), with an effect size of 0.15 , an alpha value of the traditionally utilized $5 \%$ and with a power of $95 \%$. The total desired sample size calculated was $580(n)$. The small effect size was determined on the basis of previous metanalyses on social facilitation (Bond \& Titus, 1983). Descriptive statistics and normality of data was assessed. The focus on within-change in the study violated the independence assumption of a Pearson's chi-square analysis. Thus, the marginal homogeneity test was carried out. The marginal homogeneity test is the equivalent of a Pearson's chi-square, but also an extension of a McNemar test; however, in a McNemar analysis, only 2x2 designs may be tested for. In contrast, the marginal homogeneity test allows for the comparison of multiple categories simultaneously (Dunnigan, 2013). The bouts in the condition without audience were aggregated and rounded to the nearest ordinal number. Subsequent analysis compared exclusively performance in the winning bouts through Wilcoxon Signed Ranks test. The statistical analyses were carried out in SPSS IBM. 23.

\section{Results}

In total, 86 fighters and 586 bouts ( 90 without attendance; 496 with attendance) were analyzed. Out of these, eight bouts from the non-attendance condition were excluded due to being five-round bouts $(n=4)$ or ending in draws $(n=4)$. Thus, 578 bouts remained for final analysis. Out of the remaining bouts, $87(n)$ bouts had been performed during COVID-19 and $491(n)$ bouts had been performed prior to COVID-19. In total, the average bouts analyzed per fighter were $=6 \pm 2$.

Kolmogorov-Smirnov tests indicated that performance did not follow a normal distribution in the COVID-19 condition, nor in the non-COVID-19 condition. Furthermore, the marginal test of homogeneity did indicate significant differences between the conditions, $x^{2}(14)=409.5, p<.001$. In 
other words, there were significant indicators of superior performance when competing without audience. The results are visualized in Figure 1 below.

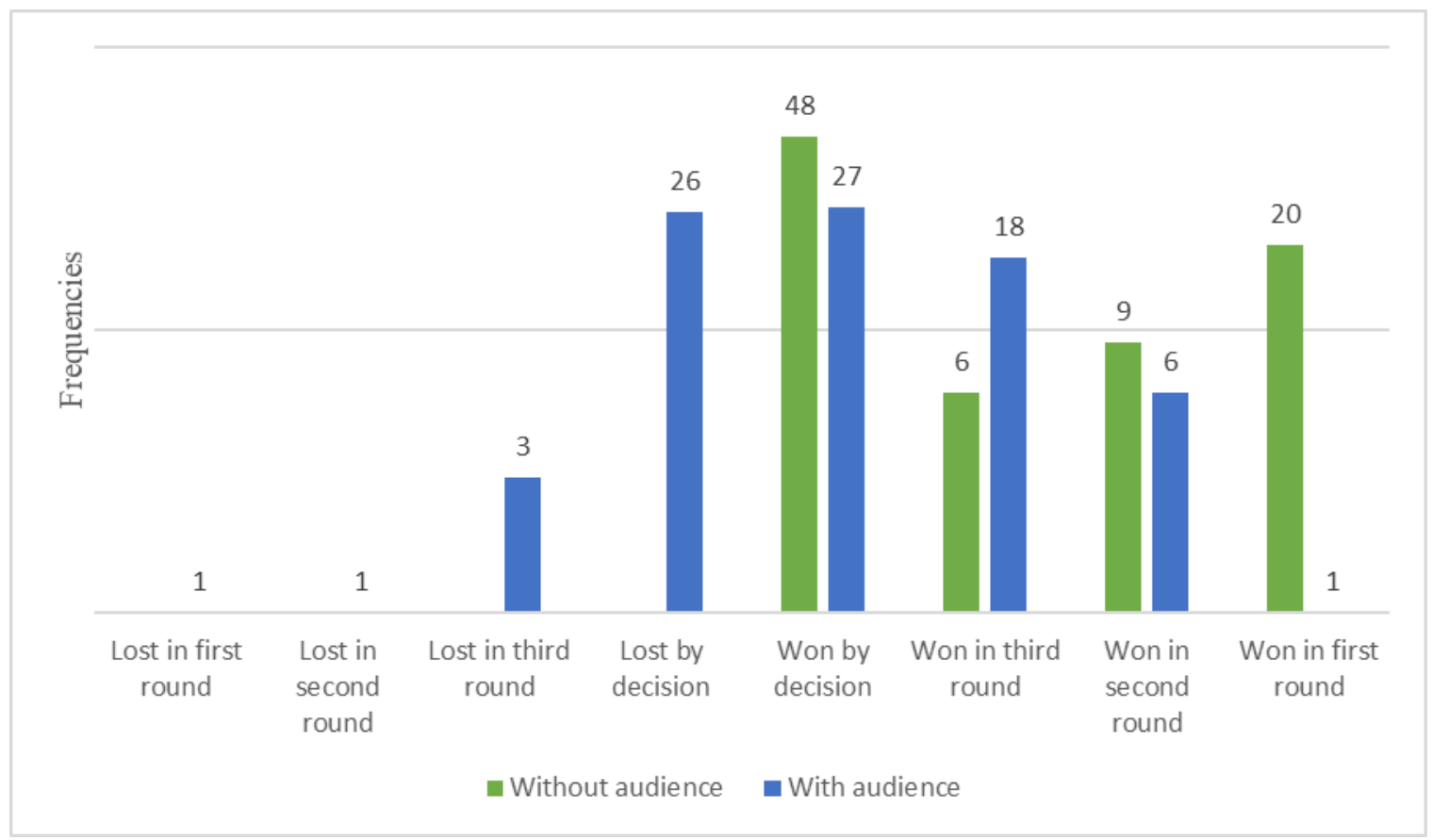

Figure 1. Frequencies on each level separated by the with- and without audience condition.

Subsequently, we removed all of the losses to make a more fine-grained comparison in performance; thus, we compared the performance in both conditions in the winning bouts. To this end, we calculated the time of the bouts: 15 minutes constituted the maximum, in other words winning by decision. Again, the data was found to be non-normally distributed, and a Wilcoxon Signed Ranks test was conducted. The results revealed yet again that, even when excluding lost bouts, the performance was still superior in the no audience condition $(p<.01)$. The results are visualized in Figure 2

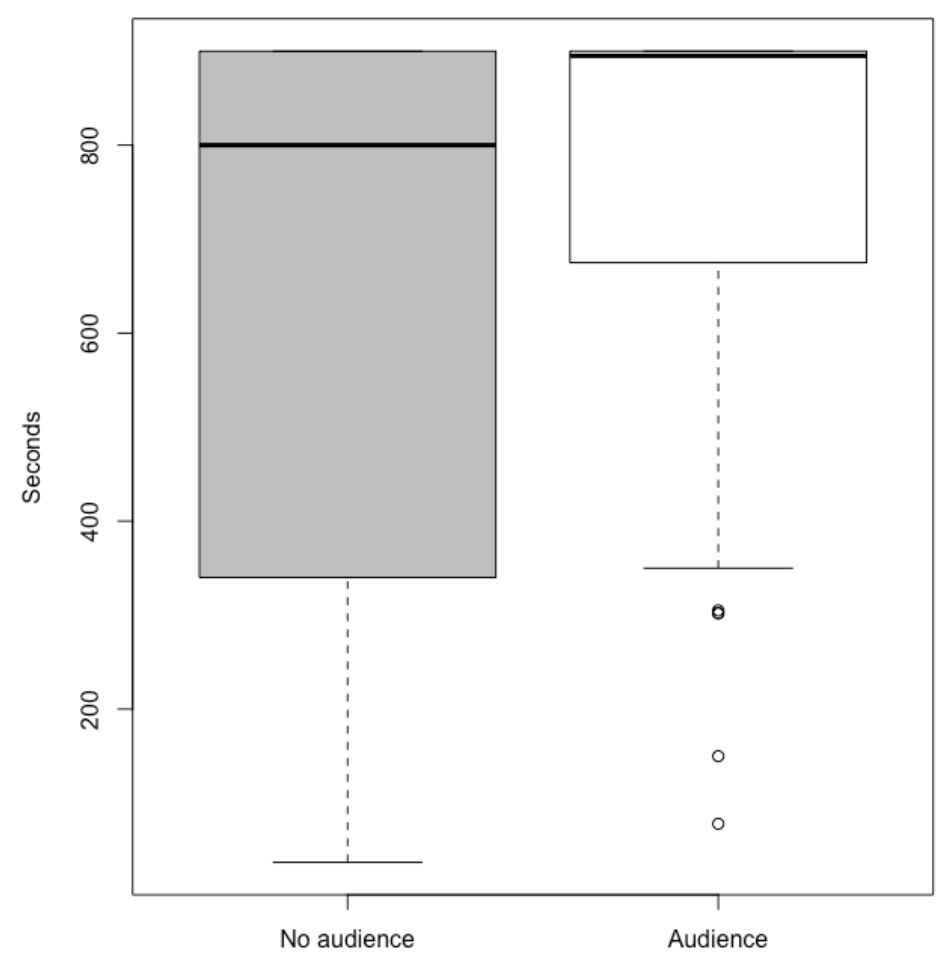

Figure 2. Winning bout duration measured in seconds between the no audience and audience condition. 


\section{Discussion}

The current study sought to compare within-differences of the winners in MMA bouts without audience with audience attended bouts. Drawing from the results, there was a significant difference between the two conditions, in which the bouts without audience were characterized by superior performance. Additionally, the study sought to detect variation even in winning bouts due to the experimental condition, which rendered significant results. In other words, despite additionally comparing exclusively bouts that were won, performance was still significantly better in the no audience condition. However, it should be noted that due to the study limitations in terms of sample size and observations in the experimental condition, the current study ought to be considered of preliminary nature.

Indeed, although audience attendance only constitutes a minor factor in the complex phenomenon of performance, the current sample's results indicated that the absence of an audience removed an element that effectively hindered their performance. In other words, the presence of an audience might have inferred excessive cognitive load which is difficult to handle effectively due to the explosive and dynamic character of MMA. According to previous literature, MMA practitioners experience extreme anxiety and fear prior to a bout (Vaccaro et al., 2011), and it is plausible that this anxiety is prone to mitigation if no audience attends. Additionally, Silva et al. (2016) found that MMA practitioners who were training for a bout experienced significantly higher stress and anger. While losing and physical injury contributes towards this anxiety, losing in front of your loved ones and family have been argued to constitute another core reason that exacerbates pre-bout anxiety (Ribeiro et al., 2013). Overall, the current preliminary results are well aligned with the findings of the previous literature. Additionally, despite its preliminary character, the current study does contribute with some adequate contributions; for example, the study provides quantified data that corroborates previous qualitative data (e.g., Vaccaro et al., 2011).

The effect of social facilitation has been highlighted as an effect which may both increment or decrement performance. The contrasting results have been argued to be due to the contrast between performing simple and complex tasks. Manstead and Semin (1980) argued the distinction lies in whether the task at hand needs cognitive information-processed controlling, or whether the information-processing is automated. In relation, some theoretical considerations ought to be highlighted in the current context: MMA is characterized by a very comprehensive set of both simple and complex tasks which vary on a spectrum between being cognitive and motor centered. Additionally, these two also plausibly intersect in an MMA bout. Whereas the decision-making and the emphasis on self-regulation, processing of fear and so forth may pertain to complex cognitive tasks, MMA fighters at this specific level are also highly trained athletes (Amtmann, 2004). Thus, the training in question consists of drills and sport-specific repetitions to the extent that motorrelated skills may be viewed as being simply performed ultimately. As such, MMA as a sport blend both cognitive complex elements with that of simple automated motor-processes. While physical attributes are of great importance to success in an MMA bout, high profile MMA coaches such as John Danaher argue that cognitive skills such as decision-making are of even greater importance; thus, we categorized MMA as a complex (cognitive) task and was guided by this specific theoretical orientation. Characterized by the same mix of cognitive- and motor elements, performing gymnastic tasks also resulted in decremented performance in front of an audience (Paulus et al., 1972; Paulus \& Cornelius, 1974), thus lending support to the current operationalization.

Some applied aspects for MMA athletes may be addressed due to the results. Athletes who may be prone to negative affects due to the attendance of audience may benefit from considering changes in training methods. Normally, MMA athletes conduct their day-to-day training in environments without spectators. As a result, there may be a stark contrast when competing in front of a live audience. Leading up to the competition, athletes that are affected by such external stimuli could potentially benefit from conducting sparring in front of peers and groups of spectators in order to familiarize oneself with such a scenario and actively working on cognitive strategies instead of simply experiencing it as a novelty on fight night. Plausibly, this acclimatization could mitigate the cognitive strain experienced. Linking our suggestion to another scientific domain, exposure therapy is a well-established form of therapy, mainly looking to 'expose' clients to their fears in order get acclimatized and ultimately reduce anxiety (Craske et al., 2008).

Rev. Artes Marciales Asiát., 15(2), 50-58 2020 
We suggest that the theoretical underpinnings in exposure therapy may be transferable to the current context.

One salient limitation of the current study was the experimental condition. Ideally, each fighter would have completed a number of bouts without audience. Although the study did fulfill the requirements of the a priori power analysis, it did so because of the aggregation of the bouts with audience. Unfortunately, this was a limitation that could not be addressed. Secondly, an MMA bout is obviously not merely affected by the audience; a wide array of factors exists in the current context that could impact the bout. This could include variation in training camps prior to the bout, changes in mental- and physical health, weight loss in order to make the determined weight limit and so forth. Other important factors are not only the skill level of the analyzed fighter, but also the skill level of the opponent who could directly alter the outcome of the bout. The attendance of an audience is thus only a small part of a set of mechanisms that could have an impact in the current context. The solution for this was to, when possible, include additional bouts, and to make sure that the study was equipped with adequate statistical power. Moreover, sport psychology in MMA is still poorly explored but are starting to attract scholarly attention (Ruiz Barquín et al., 2019; Silva et al., 2016). Still, it is currently unknown how mental skill sets may vary between MMA athletes; the current study was limited to winners on a theoretical basis, and never examined the losers in the bouts without audience. The study did not control for home-advantage either, which has previously been shown to affect judo competitors (Ferreira Julio et al., 2013), boxers (Balmer et al., 2005), wrestlers (Gayton, 1992) and other Olympic combat sport athletes (Franchini \& Takito, 2016). As a result, the study may partially have been affected by this confounding variable. Finally, COVID-19 has caused a major impact on training camps, and the conditions in which the study's fighters have prepared in might have differed from one another, thus potentially giving the preparatory edge to one fighter and ultimately impacting the outcome.

\section{Conclusions}

Fighters who won their bout(s) in front of no audience consistently and significantly displayed poorer performance in their bouts with audience. The current results further corroborate the notion that some individuals may be sensitive to the presence of an audience; however, due to the sample size and total number of observations of the non-audience condition, the results ought to be interpreted with caution. Due to these limitations, it is imperative to treat the current study results as highly preliminary. Finally, when engaging MMA athletes that may be prone to decrements in performance due to the presence of an audience, altering training methods and implementing audience-attended sparring's may be a viable option.

\section{References}

Amtmann, J. A. (2004). Self-reported training methods of mixed martial artists at a regional reality fighting event. Journal of Strength and Conditioning Research, 18(1), 194-196. doi: 10.1519/00124278-200402000-00029

Andrade, A., Batalha Silva, R., \& Dominski, F. H. (2020). Application of sport psychology to mixed martial arts. Kinesiology, 52(1), 94-102. doi: $10.26582 / \mathrm{k} .52 .1 .12$

Balmer, N. J., Nevill, A. M., \& Lane, A. M. (2005). Do judges enhance home advantage in European championship boxing? Journal of Sports Sciences, 23(4), 409-416. doi: $10.1080 / 02640410400021583$

Blomqvist Mickelsson, T. (2020). Modern unexplored martial arts-what can mixed martial arts and Brazilian Jiu-Jitsu do for youth development? European Journal of Sport Science, 20(3), 386393. doi: $10.1080 / 17461391.2019 .1629180$

Blue, S. (2013). Ongoing Change in the Rhythms of Mixed Martial Arts Practice. The International Journal of Sport and Society: Annual Review, 3(3), 161-170. doi: 10.18848/21527857/cgp/v03i03/53911

Böheim, R., Grübl, D., \& Lackner, M. (2019). Choking under pressure - Evidence of the causal effect of audience size on performance. Journal of Economic Behavior and Organization, 168, 76-93. doi: 10.1016/i.jebo.2019.10.001

Bond, C. F., \& Titus, L. J. (1983). Social facilitation: A meta-analysis of 241 studies. Psychological Bulletin, 94(2), 265-292. doi: 10.1037/0033-2909.94.2.265 
Carnes, A. J., Petersen, J. L., \& Barkley, J. E. (2016). Effect of Peer Influence on Exercise Behavior and Enjoyment in Recreational Runners. Journal of Strength and Conditioning Research, 30(2), 497-503. doi: 10.1519/JSC.0000000000001064

Claypoole, V. L., \& Szalma, J. L. (2018). Facilitating sustained attention: Is mere presence sufficient? American Journal of Psychology, 131(4), 417-428. doi: 10.5406/amerjpsyc.131.4.0417

Craske, M. G., Kircanski, K., Zelikowsky, M., Mystkowski, J., Chowdhury, N., \& Baker, A. (2008). Optimizing inhibitory learning during exposure therapy. Behaviour Research and Therapy, 46(1), 5-27. doi: 10.1016/j.brat.2007.10.003

Dunnigan, K. (2013). Tests of marginal homogeneity and special cases. Pharmaceutical Statistics, 12(4), 213-216. doi: $10.1002 /$ pst.1573

Edwards, A. M., Dutton-Challis, L., Cottrell, D., Guy, J. H., \& Hettinga, F. J. (2018). Impact of active and passive social facilitation on self-paced endurance and sprint exercise: Encouragement augments performance and motivation to exercise. BMJ Open Sport and Exercise Medicine, 4, e000368. doi: 10.1136/bmjsem-2018-000368

Ferreira Julio, U., Panissa, V. L. G., Miarka, B., Takito, M. Y., \& Franchini, E. (2013). Home advantage in judo: A study of the world ranking list. Journal of Sports Sciences, 31(2), 212-218. doi: $10.1080 / 02640414.2012 .725855$

Franchini, E., \& Takito, M. Y. (2016). Home advantage in combat sports during the Olympic Games. Sport Sciences for Health, 12(3), 287-290. doi: 10.1007/s11332-016-0286-9

García, R. S., \& Malcolm, D. (2010). Decivilizing, civilizing or informalizing? the international development of mixed martial arts. International Review for the Sociology of Sport, 45(1), 3958. doi: $10.1177 / 1012690209352392$

Gayton, W. F. (1992). Home Advantage: Does It Exist in Individual Sports. Perceptual and Motor Skills, 74(3), 706. doi: $10.2466 / \mathrm{pms} .74 .3 .706-706$

Greer, D. L. (1983). Spectator Booing and the Home Advantage: A Study of Social Influence in the Basketball Arena. Social Psychology Quarterly, 46(3), 252-261. doi: 10.2307/3033796

Hibbert, A. W., Billaut, F., Varley, M. C., \& Polman, R. C. J. (2018). Goal orientation and the presence of competitors influence cycling performance. Frontiers in Psychology, 9(1212). doi: $10.3389 /$ fpsyg.2018.01212

James, L. P., Haff, G. G., Kelly, V. G., \& Beckman, E. M. (2016). Towards a Determination of the Physiological Characteristics Distinguishing Successful Mixed Martial Arts Athletes: A Systematic Review of Combat Sport Literature. Sports Medicine, 46(10), 1525-1551. doi: 10.1007/s40279-016-0493-1

James, L. P., Sweeting, A. J., Kelly, V. G., \& Robertson, S. (2019). Longitudinal Analysis of Tactical Strategy in the Men's Division of the Ultimate Fighting Championship. Frontiers in Artificial Intelligence, 2. doi: $10.3389 /$ frai.2019.00029

Jensen, P., Roman, J., Shaft, B., \& Wrisberg, C. (2013). In the cage: MMA fighters' experience of competition. Sport Psychologist, 27(1), 1-12. doi: 10.1123/tsp.27.1.1

Kirk, C., Clark, D. R., Langan-Evans, C., \& Morton, J. P. (2020). The physical demands of mixed martial arts: A narrative review using the ARMSS model to provide a hierarchy of evidence. Journal of Sports Sciences, 1-23. doi: 10.1080/02640414.2020.1802093

La Bounty, P., Campbell, B. I., Galvan, E., Cooke, M., \& Antonio, J. (2011). Strength and conditioning considerations for mixed martial arts. Strength and Conditioning Journal, 33(1), 56-67. doi: 10.1519/SSC.0b013e3182044304

Manstead, A. S. R., \& Semin, G. R. (1980). Social facilitation effects: Mere enhancement of dominant responses? British Journal of Social and Clinical Psychology, 19(2), 119-135. doi: 10.1111/j.2044-8260.1980.tb00937.x

Miarka, B., Coswig, V. S., \& Amtmann, J. (2019). Long MMA fights technical-tactical analysis of mixed martial arts: implications for assessment and training. International Journal of Performance Analysis in Sport, 19(2), 153-166. doi: 10.1080/24748668.2019.1579030

Paulus, P. B., \& Cornelius, W. L. (1974). An analysis of gymnastic performance under conditions of practice and spectator observation. Research Quarterly of the American Alliance for Health, Physical Education and Recreation, 45(1), 56-63. doi: 10.1080/10671188.1974.10615240

Paulus, P. B., Shannon, J. C., Wilson, D. L., \& Boone, T. D. (1972). The effect of spectator presence on gymnastic performance in a field situation. Psychonomic Science, 29(2), 88-90. doi: $\underline{10.3758 / \mathrm{BF} 03336578}$ 
Reade, J. J., Schreyer, D., \& Singleton, C. (2020). Echoes: What Happens when Football Is Played behind Closed Doors? SSRN Electronic Journal, March. doi: 10.2139/ssrn.3630130

Ribeiro, V. B., Oliveira, S. R. G. de, \& Silva, F. G. da. (2013). Preditores psicológicos, reações e o processo de intervenção psicológica em atletas lesionados. Ciências e Cognição, 18(1), 70-88. doi: http://cienciasecognicao.org/revista/index.php/cec/article/view/778

Ruiz Barquín, R., Gutiérrez García, C., \& Plura Maldonado, A. (2019). Psychological characteristics of developing excellence in mixed martial arts athletes. Revista de Artes Marciales Asiáticas, 14(2s), 37-39. doi: 10.18002/rama.v14i2s.6005

Sheridan, A., Marchant, D. C., Williams, E. L., Jones, H. S., Hewitt, P. A., \& Sparks, A. (2019). Presence of Spotters Improves Bench Press Performance: A Deception Study. Journal of Strength and Conditioning Research, 33(7), 1755-1761. doi: 10.1519/ISC.0000000000002285

Silva, R. B., Andrade, A., Brandt, R., Flores Junior, M. A., \& Coimbra, D. R. (2016). Scheduled fight affect mood states of MMA athletes. Revista de Artes Marciales Asiáticas, 11(2s), 94-95. doi: 10.18002/rama.v11i2s.4189

Spencer, D. C. (2009). Habit(us), body techniques and body callusing: An ethnography of mixed martial arts. Body and Society, 15(4), 119-143. doi: 10.1177/1357034X09347224

Triplett, N. (1898). The Dynamogenic Factors in Pacemaking and Competition. The American Journal of Psychology, 9(4), 507. doi: $10.2307 / 1412188$

Vaccaro, C. A., Schrock, D. P., \& McCabe, J. M. (2011). Managing emotional manhood: Fighting and fostering fear in mixed martial arts. Social Psychology Quarterly, 74(4), 414-437. doi: 10.1177/0190272511415554

Viner, R. M., Russell, S. J., Croker, H., Packer, J., Ward, J., Stansfield, C., Mytton, O., Bonell, C., \& Booy, R. (2020). School closure and management practices during coronavirus outbreaks including COVID-19: a rapid systematic review. The Lancet Child and Adolescent Health, 4(5), 397-404. doi: $\underline{10.1016 / S 2352-4642(20) 30095-X}$

\section{Author's biographical data}

Tony Blomqvist Mickelsson (Sweden). Currently a Ph.D. Student in Social Work at Södertörn University, Tony is a former professional MMA-athlete with a number of bouts in different combat sports disciplines. A former full-time MMA coach, Tony has trained and competed with the Nordic MMA elite in several Scandinavian countries. E-mail: Tony.blomqvist@psyk.uu.se

Vince Shaw (Sweden). Vince is a former MMA-coach and currently senior sport journalism student at Södertörns högskola. E-mail: Vinceshaw0@gmail.com 